\title{
STRATEGI KETIDAKSANTUNAN BERBAHASA PADA KOLOM KOMENTAR MEDIA SOSIAL INSTAGRAM AKUN DETIKCOM: STUDI KASUS REYNHARD SINAGA
}

\author{
Yeni Tamara Supa'at ${ }^{1}$, Retnowaty ${ }^{2}$, Indah Ika Ratnawati ${ }^{3}$ \\ Universitas Balikpapan ${ }^{1}$, Universitas Balikpapan ${ }^{2}$, Universitas Balikpapan ${ }^{3}$ \\ Pos-el: yenitamara1818@gmail.com¹, retnowaty@uniba-bpn.ac.id ${ }^{2}$, \\ indah.ika@uniba-bpn.ac.id ${ }^{3}$
}

\begin{abstract}
ABSTRAK
Penelitian ini dilatarbelakangi oleh perkembangan teknologi yang pesat sehingga membuat masyarakat dapat secara bebas berkomunikasi antar sesama melalui media sosial. Hal tersebut membuat banyaknya ditemukan bahasa-bahasa kurang santun yang dilontarkan dengan berbagai cara. Cara-cara seseorang dalam berbahasa tidak santun tersebut merupakan bentuk penggunaan strategi ketidaksantunan berbahasa. Penelitian ini bertujuan untuk mendeskripsikan Strategi ketidaksantunan berbahasa pada kolom komentar media sosial instagram akun detikcom: Studi kasus Reynhard Sinaga. Penelitian ini merupakan penelitian kualitatif dengan menggunakan kajian pragmatik. Data dalam penelitian ini berupa kata, frasa atau kalimat komentar masyarakat yang diperoleh dari kolom komentar pada akun Instagram detikcom mengenai kasus Reynhard yang mengandung unsur penggunaan strategi ketidaksantunan berbahasa. Teknik pengumpulan data yang digunakan adalah teknik simak, dan catat. Teknik analisis data menggunakan model interaktif Miles dan Huberman. Penggunaan strategi yang paling banyak ditemukan adalah strategi ketidaksantunan berbahasa negatif yaitu sebanyak 219 data dan strategi yang tidak ditemukan dalam penelitian ini adalah pemakaian strategi menahan kesantunan. Hal tersebut terjadi karena strategi menahan kesantunan hanya terjadi pada komunikasi lisan.
\end{abstract}

\section{Kata kunci: Pragmatik, Strategi ketidaksantunan Culpeper, Reynhard, Instagram}

ABSTRACT

This research is motivated by the rapid development of technology that allows people to freely communicate with each other through social media. Many found impolite languages spoken in various ways and ways someone in polite language is a form of using impoliteness strategies. This study aims to describe the strategy of impoliteness of language in the social media comment column instagram account detikcom: Reynhard Sinaga case study. This research is a qualitative research using pragmatic studies. The data in this study are in the form of words, phrases or sentences of community comments obtained from the comments column on the detikcom Instagram account regarding the Reynhard case which contains elements of using language impoliteness strategies. Data collection techniques used are listening techniques, and note it. Data analysis techniques using the interactive model of Miles and Huberman. The most widely used strategy is the negative language impoliteness strategy, which is 219 data and the strategy not found in this study is the use of politeness restraint strategy.

\section{Keywords: Pragmatics, Culpeper Impoliteness Strategy, Reynhard, Instagram}

\section{PENDAHULUAN}

Perkembangan teknologi yang pesat membuat masyarakat dapat secara bebas berkomunikasi antar sesama melalui media sosial. Bahasa yang memiliki peran penting dalam berkomunikasi membuat bahasa tidak dapat dipisahkan dari kehidupan manusia karena digunakan untuk membangun ide dan menyampaikan informasi antara satu sama lain (Damayanti, 2015, p. 15) Manusia menggunakan bahasa berdasarkan kebutuhan, gaya dan cara mereka masingmasing. 
Beberapa gaya dan cara manusia dalam berbahasa di antaranya ada yang sering memperhatikan pilihan kata yang akan digunakan. Hal ini terkait fenomena kesantunan yang biasanya dapat ditemukan di bahasa (Retnowaty, 2015). Pada sisi lain, ada orang yang tidak memikirkan pilihan kata. Ketika mereka mengabaikan pilihan kata, mereka bisa saja menggunakan bahasa yang tidak santun. Ada banyak fenomena bahasa yang bisa diamati. Fenomena itu bisa diamati dari cara orang menggunakan bahasa untuk berkomunikasi (Shinta et al., 2018, p. 225-226).

Cara orang menggunakan bahasa untuk berkomunikasi selalu berubah menyesuaikan ruang dan waktu berdasarkan konteks sosial. Saat ini, orang menggunakan media sosial untuk berkomunikasi satu sama lain karena seiring perkembangan teknologi media komunikasi juga ikut berkembang. Banyaknya penggunaan media sosial ikut berdampak pada cara orang berkomunikasi, dan cara orang bereaksi terhadapnya juga ikut berubah. Percakapan tidak lagi sepenuhnya merupakan tindakan tatap muka atau obrolan sederhana melalui telepon melainkan dapat dilakukan tanpa bertemu langsung atau bertatap muka dalam jarak yang sangat jauh sekalipun dengan bantuan media sosial yang ada (Shinta et al., 2018, p. 226).

Penggunaan media sosial membuat orang bereaksi berbeda ketika mereka dalam komunikasi tatap muka dan komunikasi secara online. Dalam komunikasi tatap muka, orang cenderung tidak mengatakan apa yang ada dipikiran mereka secara langsung untuk menghindari ketidaksetujuan objek tuturan. Berkomunikasi online membuat mereka tidak takut untuk berbicara atau berperilaku bebas secara tidak tepat karena mereka tidak melihat satu sama lain. Banyak ditemukan bahasa-bahasa kurang santun yang dilontarkan dengan berbagai cara seperti secara langsung dan transparan oleh pengguna media sosial dengan didukung adanya pengggunaan makian. Selain itu sebagian juga dilakukan dengan cara penggunaan bahasa yang terlihat santun, namun sebenarnya menukik dan ditujukan dengan maksud menghina atau mencemooh seseorang atau kejadian yang tengah menjadi pembicaraan publik.

Salah satu media sosial yang dapat digunakan untuk obrolan pribadi maupun secara umum adalah Instagram. Berdasarkan hasil observasi peneliti didapati bahwa sejak tahun 2017 hingga tahun 2020 Instagram tercatat sebagai media sosial dimana cyber bullying paling sering terjadi. Selain itu, penggunaan Instagram di Indonesia menduduki posisi keempat di dunia mengalahkan Meksiko, Filipina, Rusia, Turki dan Jepang. Salah satu akun berita popular di Instagram adalah akun detikcom. Akun detikcom memiliki pengikut lebih banyak dibandingkan akun berita Indonesia lainnya di Instagram yaitu sebanyak 2,1 juta pengikut aktif pada awal 2020 dan berpotensi untuk terus bertambah. Ketika menanggapi peristiwa-peristiwa yang diberitakan orang akan cenderung lebih bersikap emosional ketika mendiskusikan beberapa masalah terlebih jika mengenai kejahatan sosial.

Salah satu kejahatan sosial yang sempat marak dibicarakan adalah mengenai kasus Reynhard Sinaga yang sangat menggemparkan publik, tidak hanya di Indonesia tetapi juga didunia. Reynhard diberitakan sebagai predator seks terbesar dalam sejarah Inggris karena memperkosa 48 pria di kota Manchester negara Inggris. Masyarakat menulis banyak komentar kasar di kolom komentar akun Instagram detikcom perihal kasus Reynhard ini. Orang-orang sangat marah kepadanya karena aksinya sehingga terus menulis komentar buruk pada setiap posting-an tentang dirinya. Tidak hanya sekedar menulis komentar buruk, namun cara masyarakat dalam menuliskan komentar-komentar tersebut digunakan sebagai sarana untuk menyerang wajah lawan. Fenomena tersebut memperlihatkan bahwa masyarakat telah menggunakan strategi-strategi untuk menghakimi Reynhard dalam bentuk ketidaksantunan berbahasa. Hal ini tentunya berkaitan dengan masalah pragmatik yang secara spesifik merujuk pada penggunaan strategi ketidaksantunan. Sesuai dengan 
masalah yang ada, Culpeper (1996) memaparkan lima strategi ketidaksantunan sebagai sarana menyerang muka yaitu ketidaksantunan berbahasa secara langsung, positif, negatif, sarkasme atau kesantunan semu, dan menahan kesantunan. Muka yang dimaksud di sini bukan merupakan bagian tubuh atau wajah yang sebenarnya. Achmad, dkk. (2020) menyatakan bahwa konsep muka adalah citra yang harus dijaga dan dipelihara oleh setiap orang agar orang lain tidak memandang rendah dirinya.

Salah satu penelitian relevan sebelumnya yang membahas tentang topik ini dalam konteks yang berbeda yaitu penelitian yang dilakukan oleh Vini Mara Shinta, Hamzah, dan Delvi Wahyuni (2018) mengenai strategi ketidaksantunan yang digunakan oleh pendukung dan penentang Ahok dalam komentar di media sosial. Hasil penelitian menunjukkan terdapat empat dari lima strategi yang ditemukan dalam penelitian ini yaitu ketidaksantunan secara langsung, positif, negatif, dan sarkasme atau sindiran. Strategi yang paling banyak digunakan adalah ketidaksantunan positif dengan pengguna tertinggi ketidaksantunan positif adalah kelompok pria (52\%).

Setelah mendalami lebih dalam peneliti menemukan bahwa pemahaman mengenai strategi ketidaksantunan berbahasa dapat memberi pemahaman bahwa tidak semua orang peka dengan apa yang disampaikan, adapula orang yang mengira apa yang diucapkan oleh orang lain merupakan bahasa yang santun, tetapi sebenarnya bahasa yang digunakan merupakan bahasa yang tidak santun. Hal tersebut terjadi karena adanya penghalusan kalimat. Tujuannya adalah untuk menyampaikan ketidaksenangan, dan ketidaksetujuan, tapi tetap ingin menghindari resiko terjadinya sebuah perselisihan, dan mengurangi kekasaran verbal yang berlebih.

Namun untuk sebagian orang, dalam penyampaian opini untuk menunjukkan ketidaksetujuan, penolakan, beberapa orang juga tetap menggunakan bahasa tidak santun secara jelas, tanpa menggunakan kata, frasa atau kalimat pengganti yang lebih halus, dengan tujuan agar maksud yang ingin disampaikan dapat lebih cepat dan segera dipahami oleh lawan tutur. Hal-hal tersebut memperlihatkan bahwa adanya strategistrategi yang digunakan untuk berbahasa secara tidak santun.

Oleh karena itu, peneliti mengkaji mengenai pragmatik yang berkaitan dengan strategi ketidaksantunan berbahasa dengan judul "Strategi ketidaksantunan berbahasa pada kolom komentar media sosial Instagram akun detikcom: Studi kasus Reynhard Sinaga".

Berdasarkan latar belakang yang telah diuraikan, maka rumusan masalah dalam penelitian ini adalah bagaimanakah bentuk strategi ketidaksantunan berbahasa pada kolom komentar akun detikcom media sosial Instagram: studi kasus Reynhard Sinaga?. Berdasarkan rumusan masalah tersebut, maka tujuan penelitian ini adalah untuk mendeskripsikan bentuk strategi ketidaksantunan berbahasa pada kolom komentar akun detikcom media sosial Instagram: studi kasus Reynhard Sinaga.

\section{Strategi Ketidaksantunan Berbahasa}

Culpeper (1996, p. 8) mendefinisikan lima strategi ketidaksantunan berbahasa yaitu ketidaksantunan secara langsung (bald on record impoliteness), ketidaksantunan positif (positive impoliteness), ketidaksantunan negatif (negative impoliteness), sarkasme atau kesantunan semu (sarcasm or mock politeness), dan menahan kesantunan (withhold politeness).

a. Ketidaksantunan secara langsung,

Merupakan tindakan untuk mengancam muka subjek lawan atau objek tuturan secara langsung, jelas, ringkas dan tidak ambigu dalam keadaan muka tidak relevan atau diminimalkan dan tidak perlu dihubungkan dengan muka.

b. Ketidaksantunan positif

Merupakan strategi yang digunakan dengan tujuan untuk merusak muka positif target tuturan. Ciri-ciri ketidaksantunan positif antara lain, tidak simpatik, mengabaikan atau menganggap target bicara tidak ada, menggunakan sebutan atau penanda identitas dengan tidak tepat dan di 
sengaja, menggunakan bahasa rahasia atau yang tidak dapat dimengerti target tuturan, menggunakan bahasa tabu, menggunakan julukan yang menghina, dan sebagainya.

c. Ketidaksantunan negatif

Merupakan strategi ketidaksantunan yang digunakan dengan tujuan untuk merusak muka negatif target tuturan. Penanda penggunaan Strategi ini antara lain, menakutnakuti (menanamkan sugesti atau keyakinan bahwatindakannya tersebut akan merugikan dirinya maupun orang lain), menghina, mencemooh, mengejek, merendahkan, melecehkan, tidak memperlakukan target tuturan dengan serius, meremehkan (menganggap kecil target tuturan.

d. Sarkasme atau kesantunan semu

Merupakan strategi ketidaksantunan yang digunakan dengan penyampaian yang jelas tidak tulus, berpura-pura, atau tampak santun dipermukaan saja.

e. Menahan kesantunan

Merupakan tindakan ketidaksantunan dimana pelaku tidak melakukan strategi kesantunan seperti yang diharapkan, misalnya seperti tidak mengucapkan terima kasih kepada target tuturan yang memberikan hadiah atau memberikan ucapan selamat.

\section{METODE PENELITIAN}

Penelitian ini merupakan jenis penelitian kualitatif. Dalam penelitian kualitatif, peneliti sendiri atau bantuan orang lain merupakan alat pengumpul data yang utama (Moleong, 2014, p. 9). Instrumen penelitian ini adalah peneliti sendiri dan peneliti di bantu dengan gawai, wifi atau data seluler, alat tulis, laptop dan kartu data .

Dalam penelitian menggunakan teknik pengumpulan data berupa teknik simak dan catat. Mahsun ( 2012, p. 92) memaparkan bahwa teknik simak yang digunakan untuk memperoleh data dilakukan dengan menyimak penggunaan bahasa. Teknik ini dilakukan untuk menyimak dan mengetahui kata atau kalimat komentar yang disampaikan oleh masyarakat terhadap kasus Reynhard Sinaga pada akun Instagram detikcom. Kemudian teknik catat adalah teknik lanjutan ketika menerapkan metode simak. Teknik ini digunakan untuk mencatat komentar-komentar yang dihasilkan komentar yang disampaikan oleh masyarakat terhadap kasus Reynhard sinaga pada akun Instagram detikcom.

Sumber data dalam penelitian adalah dari objek yang diteliti, tempat di mana data diperoleh. Arikunto (2010, p. 172) menyatakan bahwa sumber data merupakan tempat asal dimana data tersebut diperoleh. Sumber data penelitian ini diambil dari kolom komentar media sosial Instagram mengenai kasus Reynhard Sinaga yang diposting oleh akun detikcom pada bulan Januari hingga bulan Maret 2020 yaitu dengan jumlah komentar terbanyak adalah 1.992 komentar. Wujud dari data ini berupa kata, frasa atau kalimat komentar masyarakat yang diperoleh dari kolom komentar pada akun Instagram detikcom yang mengandung unsur penggunaan strategi ketidaksantunan berbahasa.

Data dalam penelitian ini diperoleh dari hasil kata, frasa atau kalimat komentar masyarakat yang diperoleh dari kolom komentar pada akun detikcom media sosial Instagram, analisis data dilakukan dengan cara mengorganisir data yang diperoleh kedalam sebuah kategori, menjabarkan kedalam unit-unit, menganalisis data yang penting dan diperlukan, kemudian menyajikan data sesuai dengan rumusan masalah dalam bentuk laporan atau membuat kesimpulan agar mudah untuk dipahami.

Sesuai dengan penjelasan tersebut peneliti menggunakan model interaktif dari Miles dan Huberman (Sugiyono, 2015, p. 246) untuk menganalisis data dari hasil penelitian. Aktivitas dalam analisis data kualitatif terjadi secata terus-menerus hingga tuntas. Beberapa langkah yang dilakukan dalam proses analisis data yaitu:

1) Reduksi Data

Reduksi data dilakukan untuk memisahkan semua data sesuai dengan kesatuannya. Data akan disusun secara sistematis untuk mempermudah peneliti melakukan pengamatan dan memberi gambaran tentang hasil pengamatan. Reduksi data juga dapat digunakan untuk 
mempermudah pemberian kode data sesuai dengan kategorinya yaitu: strategi ketidaksantunan berbahasa secara langsung, positif, negatif, sarkasme dan menahan kesantunan yang terdapat pada komentar masyarakat dalam kolom komentar postingan Reynhard Sinaga pada akun Instagram detikcom.

2) Data display (penyajian data).

Langkah selanjutnya dalam analisis data kualitatif setelah mereduksi data adalah mendisplaykan data atau penyajian data. dalam penelitian kualitatif, penyajian data bisa dilakukan dalam bentuk uraian singkat, bagan, hubungan antar kategori, flowchart, dansejenisnya. Yang paling sering digunakan untuk menyajikan data dalam penelitian kualitatif adalah dengan teks yang bersifat naratif.

3) Penarikan kesimpulan/verification.

Peneliti harus banyak membaca dari berbagai sumber terutama penelitian terdahulu. Memahami makna data yang dikumpulkan, berusaha menyimpulkannya. Untuk kesimpulan pertama masih terbilang samar-samar dalam artian masih kurang jelas dalam menyimpulkan. Setelah data terkumpul untuk kesimpulan yang didapat akan lebih jelas.

Moleong (2014, p. 321) menyatakan keabsahan data merupakan konsep penting yang diperbaharui dan paling sederhana bahwa temuan-temuan peneliti dapat dipercaya atau dapat dipertimbangkan. Penelitian ini menggunakan teknik pemeriksaan keabsahan data menggunakan ketekunan atau keajegan pengamatan dan triangulasi. Ketekunan dalam penelitian adalah tekun dalam membaca dan menyimak secara lebih cermat dan berkesinambungan. Dengan ketekunan pengamatan, maka peneliti dapat melakukan pengecekan kembali dan membaca secara berulang-ulang dengan tekun data yang didapatkan yaitu berupa komentar-komentar masyarakat mengenai kasus Reynhard Sinaga pada kolom komentar akun Instagram detikcom. Selain itu, peneliti juga dapat memberikan deskripsi data yang akurat dan sistematis tentang apa yang diamati.
Selanjutnya teknik lain yang digunakan adalah triangulasi. Triangulasi adalah suatu teknik pemeriksaan keabsahan atau kepastian data yang memanfaatkan sesuatu hal yang lain. Penelitian ini menggunakan jenis triangulasi penyidik untuk keperluan pengecekan kembali derajat kepercayaan data dan membantu peneliti mengurangi kemelencengan dalam pengumpulan data. Adapun penyidik yang akan melakukan pengecekan kembali derajat kepercayaan ini adalah bapak Syamsul Rijal, M. Hum dosen pengampu mata kuliah Pragmatik di Universitas Mulawarman, Samarinda.

\section{HASIL DAN PEMBAHASAN}

Tidak seperti penelitian relevan lain yang hanya memaparkan penggunaan strategi ketidaksantunan berbahasa Culpeper (1996) secara tunggal, dalam hasil penelitian ini menunjukkan bahwa strategi-strategi tersebut tidak hanya digunakan secara tunggal, tetapi juga menunjukkan adanya penggunaan kombinasi antar strategi tersebut. Hal ini membuat penelitian ini berbeda dengan penelitian relevan lainnya. Diagram pie dibawah ini menunjukkan jenis strategi yang digunakan oleh masyarakat Indonesia pada kolom Instagram detikcom posting-an kasus Reynhard Sinaga.

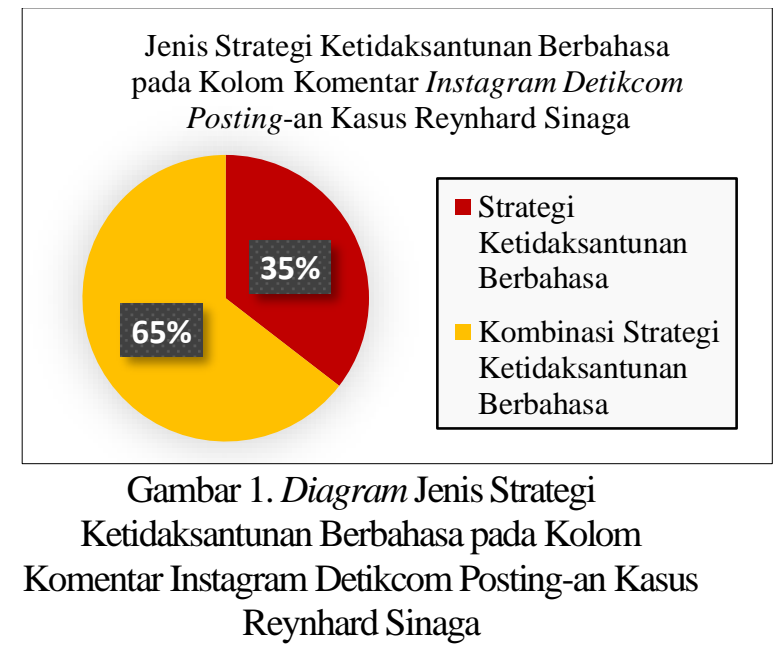

Berdasarkan diagram pie tersebut, dapat terlihat bahwa sebagian besar komentator dalam kolom komentar Instagram detikcom mengenai kasus Reynhard Sinaga menggunakan kombinasi strategi 
ketidaksantunan berbahasa. Hasil penelitian menunjukkan $\quad 65 \% \quad$ komentator menggunakan kombinasi strategi ketidaksantunan berbahasa, ini berarti komentator cenderung menggunakan lebih dari satu strategi dalam berbahasa tidak santun. Komentator menggunakan dua hingga tiga strategi yang digabungkan dalam satu komentar yang tidak santun. Hasil penelitian juga menunjukkan hanya $35 \%$ komentator yang menggunakan strategi ketidaksantunan berbahasa secara tunggal, artinya penggunaan kombinasi strategi ketidaksantunan berbahasa cenderung lebih tinggi dibandingkan penggunaan strategi ketidaksantunan berbahasa secara tunggal. Jumlah strategi ketidaksantunan berbahasa baik secara tunggal maupun kombinasi yang ditemukan dalam penelitian ini adalah sejumlah 846 data. Setiap jenis strategi tersebut diuraikan sebagai berikut.

Tabel berikut ini menunjukkan strategi ketidaksantunan berbahasa yang digunakan oleh komentator dalam kolom komentar Instagram detikcom mengenai kasus Reynhard Sinaga.

Tabel 1. Strategi Ketidaksantunan Berbahasa pada Kolom Instagram Detikcom Posting-an Kasus Reynhard Sinaga

\begin{tabular}{|l|c|c|}
\hline \multicolumn{1}{|c|}{$\begin{array}{c}\text { Strategi } \\
\text { Ketidaksantunan } \\
\text { Berbahasa }\end{array}$} & F & Persen \\
\hline Secara Langsung & 0 & $0 \%$ \\
\hline Positif & 13 & $4,33 \%$ \\
\hline Negatif & 219 & $73 \%$ \\
\hline $\begin{array}{l}\text { Sarkasme atau Kesantunan } \\
\text { Semu }\end{array}$ & 68 & $22,67 \%$ \\
\hline Menahan Kesantunan & 0 & $0 \%$ \\
\hline Jumlah & $\mathbf{3 0 0}$ & $\mathbf{1 0 0 \%}$ \\
\hline
\end{tabular}

Seperti yang ditunjukkan pada tabel 3 tersebut, penggunaan strategi ketidaksantunan berbahasa secara tunggal yang dituturkan oleh masyarakat Indonesia pada kolom Instagram detikcom posting-an kasus Reynhard Sinaga yaitu sebanyak 300 data komentar, strategi ketidaksantunan secara langsung 0 data atau sebanyak $0 \%$, strategi ketidaksantunan positif 13 data atau sebanyak 4,33\%, strategi ketidaksantunan negatif 219 data atau sebanyak $73 \%$, strategi ketidaksantunan sarkasme atau kesantunan semu 68 data atau sebanyak 22,67\% dan strategi menahan kesantunan 0 data atau sebanyak 0\%.

Seperti yang telah dipaparkan sebelumnya bahwa komentator tidak hanya menggunakan strategi ketidaksantunan berbahasa secara tunggal, tetapi juga menggunakan kombinasi strategi ketidaksantunan berbahasa. Tabel berikut ini menunjukkan kombinasi strategi ketidaksantunan berbahasa yang digunakan oleh komentator dalam kolom komentar Instagram detikcom mengenai kasus Reynhard Sinaga.

Tabel 2. Kombinasi Strategi

Ketidaksantunan Berbahasa pada Kolom Instagram Detikcom Posting-an Kasus Reynhard Sinaga

\begin{tabular}{|c|c|c|c|}
\hline Kombinasi & Strategi & $\mathbf{F}$ & Persen \\
\hline \multirow{5}{*}{$\begin{array}{l}\text { Kombinasi } \\
2 \text { Strategi }\end{array}$} & $\begin{array}{l}\text { Secara Langsung } \\
\text { + Positif }\end{array}$ & 64 & $11,72 \%$ \\
\hline & $\begin{array}{l}\text { Secara Langsung } \\
\text { +Negatif }\end{array}$ & 157 & $28.75 \%$ \\
\hline & Positif+Negatif & 156 & $28,57 \%$ \\
\hline & Positif+Sarkasme & 2 & $0,37 \%$ \\
\hline & Negatif+Sarkasme & 7 & $1,28 \%$ \\
\hline \multirow{2}{*}{$\begin{array}{l}\text { Kombinasi } \\
3 \text { Strategi }\end{array}$} & $\begin{array}{l}\text { Secara } \\
\text { Langsung+Positif } \\
\text { +Negatif }\end{array}$ & 155 & $28,34 \%$ \\
\hline & $\begin{array}{l}\text { Positif+Negatif } \\
\text { +Sarkasme }\end{array}$ & 5 & $0,92 \%$ \\
\hline \multicolumn{2}{|r|}{ Jumlah } & 546 & $100 \%$ \\
\hline
\end{tabular}

Berdasarkan hasil yang tertera pada tabel 2 tersebut, penggunaan kombinasi strategi ketidaksantunan berbahasa yang dituturkan oleh masyarakat Indonesia pada kolom Instagram detikcom posting-an kasus Reynhard Sinaga yaitu sebanyak 546 data komentar yaitu kombinasi strategi ketidaksantunan berbahasa secara langsung dan positif 64 data atau sebanyak 11,72\%, kombinasi strategi ketidaksantunan berbahasa secara langsung dan negatif 157 data atau sebanyak $28,75 \%$, kombinasi strategi ketidaksantunan berbahasa positif 
dan negatif 156 data atau sebanyak 28,57\%, kombinasi strategi ketidaksantunan berbahasa positif dan sarkasme 2 data atau sebanyak $0,37 \%$, kombinasi strategi ketidaksantunan berbahasa negatif dan sarkasme 7 data atau sebanyak 1,28\%, kombinasi strategi ketidaksantunan berbahasa secara langsung, positif dan negatif 155 data atau sebanyak 28,34\%, dan kombinasi strategi ketidaksantunan berbahasa positif, negatif, sarkasme 5 data atau sebanyak $0,92 \%$.

Persentase data didapatkan berdasarkan jumlah data yang ditemukan dibagi dengan jumlah keseluruhan tuturan atau komentar yang mengandung strategi ketidaksantunan berbahasa, kemudian dikalikan dengan 100\%. Dari 2 tabel distribusi frekuensi strategi ketidaksantunan berbahasa sebelumya dapat dilihat bahwa jumlah penggunaan strategi yang paling banyak ditemukan adalah strategi ketidaksantunan berbahasa negatif yaitu sebanyak 219 data atau sebanyak $73 \%$.

Beberapa contoh hasil penelitian tersebut sebagai berikut.

1. Strategi Ketidaksantunan Berbahasa

\section{a. Strategi Ketidaksantunan Berbahasa Positif \\ Kode data : 270/SS171/U1}

tattysufialjawi Manusia macem
ni sebaiknya di hukum sesuai
perbuatannya ya yaitu dubur deise di
coblos pake linggis yg sudah di panasin
selama dua hari dua malem

Konteks tuturan "Manusia macem ni sebaiknya di hukum sesuai perbuatannya ya yaitu dubur deise dicoblos pake linggis yg sudah di panasin selama dua hari dua malem" dituliskan oleh pemilik akun Instagram @tattysufialjwi untuk mengomentari posting-an akun Instagram detikcom berupa video mengenai kasus Reynhard Sinaga, pria indonesia yang divonis penjara seumur hidup atas dakwaan memperkosa 48 pria yang di-posting pada tanggal 7 Januari 2020. Target pada data komentar tersebut adalah Reynhard. Pemilik akun@tattysufialjwi menyerang Reynhard melalui komentar yang tidak santun atas tindakan yang dilakukan Reynhard memperkosa 48 pria dan mendapat vonis penjara seumur hidup.

Komentar "Manusia macem ni sebaiknya di hukum sesuai perbuatannya ya yaitu dubur deise dicoblos pake linggis yg sudah di panasin selama dua hari dua malem" merupakan bentuk penggunaan strategi ketidaksantunan berbahasa positif, karena komentar mengandung unsur ketidaksimpatian yang merupakan salah satu ciri dari strategi ketidaksantunan positif yang dikemukakan oleh Culpeper (1996). Dalam KBBI V kata "dubur" merupakan bentuk kata benda yang berarti lubang pada ujung bawah usus, atau anus. Lalu kata "deise" merupakan bahasa gaul yang sering dipakai oleh para banci. Penulisan yang benar adalah "deseu". Kata tersebut memiliki arti "dia". Kata "dia" pada komentar tersebut merujuk kepada Reynhard sebagai target dari tuturan tersebut, sedangkan kata "coblos" dalam KBBI V merupakan bentuk kata kerja yang berarti tusuk, sehingga ketidaksimpatian komentator terhadap target terlihat dari komentator yang ingin agar target disiksa yaitu dengan menusuk dubur target dengan linggis yang sudah di panaskan selama dua hari dua malam.

\section{b. Strategi Ketidaksantunan Berbahasa Negatif Kode data : 06/SS4/U3}

jam_ngopi @hifasi masa depan
inggris bisa suram nii kalau
ada 100 orang Reynhard di
sono wkwkw pemuda nya pada
madesu

Konteks tuturan "masa depan inggris bisa suram nii kalua ada 100 orang Reynhard di sono wkwkw pemuda nya pada madesu" dituliskan oleh pemilik akun Instagram @jam_ngopi untuk mengomentari komentar dari akun@hifasi sebelumnya yaitu "doyan bol" terkait posting-an akun Instagram detikcom berupa video mengenai kasus Reynhard Sinaga, pria Indonesia yang divonis penjara seumur hidup 
atas dakwaan memperkosa 48 pria yang diposting pada tanggal 7 Januari 2020. Target pada data komentar tersebut adalah Reynhard.

Komentar "masa depan inggris bisa suram nii kalau ada 100 orang Reynhard di sono wkwkwk pemudanya pada madesu" yang dituliskan oleh akun @jam_ngopi merupakan bentuk penggunaan strategi ketidaksantunan berbahasa negatif karena mengandung salah satu ciri strategi ketidaksantunan berbahasa negatif yang dikemukakan oleh Culpeper (1996) yaitu menghina, mencemooh, mengejek, merendahkan, dan melecehkan target. Komentator menyerang muka negatif target yaitu Reynhard dengan cara menghina dan merendahkan target. Hal tersebut terlihat dari komentator yang mengemukakan bahwa hanya dengan 100 orang Seperti Reynhard di Inggris dapat membuat masa depan inggris menjadi suram, karena pemuda-pemudanya akan "madesu". Kata "madesu" merupakan bahasa gaul yaitu singkatan dari "masa depan suram" atau memiliki masa depan yang suram hal tersebut tentu saja memperlihatkan betapa rendah dan hinanya Reynhard dimata komentator.

c. Sarkasme atau kesantunan semu Kode data : 239/SS157/U3

guruhprakoso24 Ini dia yg
mengharumkan nama Indonesia di
Inggris @balubunss

Konteks tuturan "ini dia yg mengharumkan nama Indonesia di Inggris” dituliskan oleh pemilik akun Instagram @guruhprakoso24 dengan menandai @balubunss untuk mengomentari posting-an akun Instagram detikcom berupa video mengenai kasus Reynhard Sinaga, pria indonesia yang divonis penjara seumur hidup atas dakwaan memperkosa 48 pria yang diposting pada tanggal 7 Januari 2020. Target pada data komentar tersebut adalah Reynhard. Target pada data komentar tersebut adalah Reynhard. Pemilik akun @guruhprakoso24 ingin menyerang Reynhard melalui komentar yang tidak santun namun diperhalus atas tindakan yang dilakukan Reynhard memperkosa 48 pria dan mendapat vonis penjara seumur hidup.

Komentar "ini dia yg mengharumkan nama Indonesia di Inggris" termasuk dalam strategi ketidaksantunan sarkasme atau kesantunan semu. Sarkasme dalam strategi ketidaksantunan berbahasa Culpeper (1996) tidak sama seperti sarkasme dalam majas yang berupa penghinaan yang mengekspresikan rasa kesal dan marah dengan menggunakan kata-kata yang sangat kasar, melainkan menyerang muka target tidak secara terang-terangan dengan menggunakan kalimat yang lebih halus namun sebenarnya ditujukan untuk menghina lawan. Cirinya adalah ujaran yang tidak tulus, berpura-pura dan hanya tampak santun di permukaan. Kata "mengharumkan" pada komentar "ini dia yg mengharumkan nama indonesia di inggris" merupakan kata kiasan yang dalam KBBI V berarti menjadikan masyhur atau menjadikan terkemuka, terhormat atau terkenal. Dalam konteks kalimatnya kata "mengharumkan" mengandung unsur keberpura-puraan dan ketidaktulusan karena pada kenyataannya tindak kriminal yang dilakukan Reynhard tidak mengharumkan nama Indonesia di luar negeri khususnya di Inggris, sebaliknya justru merusak atau mencoreng nama baik Indonesia.

2. Kombinasi Dua Strategi Ketidaksantunan Berbahasa

a. Kombinasi Strategi Ketidaksantunan Secara Langsung Dan Positif Kode data : 141/SS111/U1

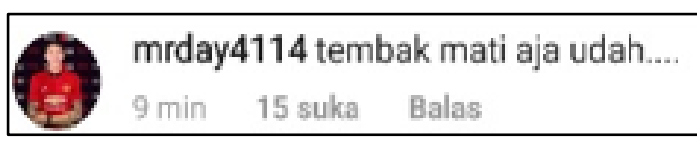

Konteks komentar tersebut dituliskan oleh pemilik akunInstagram @mrday4114 untuk mengomentari posting-an akun Instagram detikcom berupa video mengenai kasus Reynhard Sinaga, pria Indonesia yang divonis penjara seumur hidup atas dakwaan memperkosa 48 pria yang di-posting pada tanggal 7 Januari 2020. Target dalam data 
komentar tersebut adalah Reynhard. Pemilik akun Instagram @mrday4114 menyerang Reynhard melalui komentar yang tdak santun tanpa penghalusan kalimat atas tindakan yang dilakukan Reynhard memperkosa 48 pria dan mendapat vonis penjara seumur hidup.

Bentuk strategi ketidaksantunan berbahasa secara langsung dapat terlihat dari komentator yang memperlihatkan niatnya secara jelas untuk melakukan ofensif maksimal terhadap target dengan meminta yang lain untuk menembak mati target. Komentator menyerang Reynhard secara langsung tanpa penghalusan kalimat dengan komentar yang jelas, singkat dan tidak ambigu sesuai dengan ciri strategi ketidaksantunan secara langsung yang dipaparkan oleh Culpeper (1996).

Komentar tersebut juga termasuk dalam strategi ketidaksantunan berbahasa positif, karena komentar mengandung unsur ketidaksimpatian yang merupakan salah satu ciri dari strategi ketidaksantunan positif Culpeper (1996). Ketidaksimpatian itu terlihat dari komentator yang tidak besimpati pada target yang mendapat hukuman seumur hidup justru meminta agar target ditembak mati.

b. Kombinasi Strategi Ketidaksantunan Secara Langsung Dan Negatif

Kode data : 71/SS36/U1

ahmedshaleh_@movingon2 SAMPAHH GAK GUNA

Konteks komentar "SAMPAHH GAK GUNA" dituliskan oleh pemilik akun Instagram@ahmedshaleh untuk mengomentari komentar akun @ movingon2 sebelumnya yang berkomentar "Di akun NARACIAGA banyak akun VERIFIED yang comment, scroll aja" terkait posting-an akun Instagram detikcom berupa video mengenai kasus Reynhard Sinaga pria Indonesia, yang divonis penjara seumur hidup atas dakwaan memperkosa 48 pria yang di-posting pada tanggal 7 Januari 2020. Target komentar tersebut bukanlah Reynhard tetapi pemilik akun @ movingon2.

Ciri strategi ketidaksantunan secara langsung yang dikemukakan oleh Culpeper (1996) yaitu ujaran yang jelas, tidak ambigu dan dituliskan secara singkat. Pada data tersebut komentator menghina target secara langsung untuk melakukan ofensif maksimal dengan menggunakan ujaran yang jelas, singkat dan tidak ambigu. Hal ini terlihat dari komentar "SAMPAH GAK GUNA" yang secara jelas dapat dipahami dan langsung menyerang Reynhard. Penggunaan kata "SAMPAHH" dan frasa "GAK GUNA" serta penulisan komentar dengan penggunaan huruf kapital memberikan asumsi komentator seakan berteriak memberikan penekanan makian kepada target.

Data tersebut juga termasuk strategi ketidaksantunan negatif karena mengandung ciri strategi ketidaksantunan negatif Culpeper (1996) yaitu unsur mencemooh, menghina dan merendahkan. Penghinaan oleh komentator dilakukan dengan memanggil target "SAMPAH GAK GUNA". Kata sampah dalam KBBI V memiliki arti barang atau benda yang dibuang atau kotoran, akan tetapi jika dikaitkan dengan konteks komentarnya yang dimaksud adalah komentator menyamakan target dengan sampah, komentator menggap target seperti kotoran. Penambahan frasa " $G A K$ GUNA" membuat hinaan tersebut semakin nyata. Frasa tersebut jika dituliskan dalam bahasa Indonesia yang benar akan menjadi "tidak berguna". Sebutan "tidak berguna" merupakan antonim atau lawan kata dari "berguna" yang berarti berfaedah atau bermanfaat. Itu artinya penggunaan frasa " $G A K$ GUNA" untuk menyebut target yaitu Reynhard sama saja dengan menganggap target tidak bermanfaat atau tidak membawa manfaat apapun. 
c. Kombinasi Strategi Ketidaksantunan Positif Dan Negatif

Kode data :103/SS70/U3

silumankera LU SEMUA
GOBLOK, MAU KRISTEN
MAU ISLAM GOBLOK
KALIAN ANJEENG, APA2
DIHUBUNGKAN KE AGAMA.
CUIHHH,., JIJIK GUA LIAT
KELAKUAN KALIAN.

Konteks komentar "LU SEMUA

GOBLOK, MAU KRISTEN MAU ISLAM GOBLOK KALIAN ANJEENG, APA2 DIHUBUNGKAN KE AGAMA, CUIHHH..JIJIK GUA LIAT KELAKUAN KALIAN." tersebut dituliskan oleh pemilik akun Instagram @siluman kera? yang ditujukan kepada semua pengguna akun Instagram yang berkomentar dengan mengaitkan agama dalam posting-an akun Instagram detikcom berupa video mengenai kasus Reynhard Sinaga, pria Indonesia yang divonis penjara seumur hidup atas dakwaan memperkosa 48 pria yang di-posting pada tanggal 7 Januari 2020. Target dalam data komentar tersebut adalah semua komentator yang berkomentar dengan mengaitkan kasus Reynhard ini dengan agama.

Komentar tersebut termasuk dalam strategi ketidaksantunan negatif karena pada komentar tersebut komentator menghina, mencemooh dan melecehkan target dengan cara menyebut target goblok, anjing, dan memperlihatkan kejijikan komentator terhadap target melalui ungkapan "CUIHH..JIJIK GUA LIAT KELAKUAN KALIAN SEMUA”. Hal tersebut sesuai dengan teori yang dipaparkan oleh Culpeper (1996) mengenai ciri strategi ketidaksantunan negatif yaitu mencemooh atau mengejek, menghina, dan merendahkan atau melecehkan target.

Selain itu komentar " $L U$ SEMUA GOBLOK, MAU KRISTEN MAU ISLAM GOBLOK KALIAN ANJEENG" juga tergolong strategi ketidaksantunan berbahasa positif, karena komentator menggunakan bahasa tabu yaitu pada kata "goblok" dan "anjeeng". Termasuk dalam kata tabu karena merupakan kata makian. Kata makian dan tabu memiliki hubungan yang erat. Bahasa tabu adalah bahasa yang sifatnya tidak baik, sehingga seringkali dijadikan sarana melampiaskan emosi, oleh karena itu bahasa tabu sering dipakai sebagai makian. Selain itu mengandung penggunaan penanda identitas yang tidak tepat yaitu pada kata "anjeeng" dalam frasa "KALIAN ANJEENG". Kata "anjeeng" jika tuliskan dengan penulisan yang benar akan menjadi "anjing" yang berarti sebuah nama binatang. Memanggil target yang merupakan manusia dengan nama binatang, merupakan bentuk penggunaan penanda identitas yang tidak tepat. Penggunaan bahasa tabu dan penggunaan penanda identitas yang tidak tepat merupakan salah satu ciri dari strategi ketidaksantunan berbahasa positif yang dikemukakan oleh Culpeper (1996).

d. Kombinasi Strategi Ketidaksantunan Positif Dan Sarkasme

Kode data :112/SS82/U3

husna_taufik $₫$ adipati_adi
_adi santai itu ngatain orang
bodoh,santai itu ngatain
orang mabok agama trus
bilangin orang harus waras
dikitemang saya gila apa
mas?itu yang dibilang santai
brother

Konteks komentar "santai itu ngatain orang bodoh, santai itu ngatain orang mabok agama trus bilangin orang harus waras dikit, emang saya gila apa mas? Itu yang dibilang

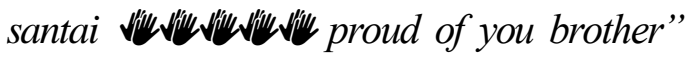
dituliskan oleh pemilik akun Instagram @husna_taufik untuk membalas komentar @adipati_adi_adi dengan username @haitommy__yang sebelumnya berkomentar “@husna_taufik situ yg lucu...ngatain ngegas...ngatain fake, pdhal gwnya sante2 aja. Aneh!" dalam posting-an akun Instagram detikcom berupa video mengenai kasus Reynhard Sinaga, pria indonesia yang divonis penjara seumur hidup atas dakwaan memperkosa 48 pria yang diposting pada tanggal 7 Januari 2020. Target dalam data komentar tersebut adalah pemilik akun Instagram @adipati_adi_adi dengan username@ haitommy. 
Selain itu komentar tersebut juga termasuk dalam strategi ketidaksantunan berbahasa positif, karena mengandung unsur bahasa tabu yang merupakan salah satu ciri dari strategi ketidaksantunan positif Culpeper (1996). Bahasa tabu terlihat dari penggunaan kata "gila". Dalam KBBI V "gila" merupakan sebuah gangguan jiwa (saraf terganggu, atau pikiran yang tidak normal) atau sakit ingatan. Kita sudah tidak boleh menggunakan istilah gila, sinting, dan lainlain karena memberikan stigma dan diskriminasi, istilah yang dipakai untuk orang dengan masalah kejiwaan saat ini adalah ODMK. Sebutan ODMK diatur dalam UU Kesehatan Jiwa No.18 tahun 2014, ODMK adalah orang yang mempunyai masalah disik, mental, sosial, pertumbuhan dan perkembangan atau kualitas hidup sehingga memiliki resiko mengalami gangguan jiwa.

Sarkasme dalam strategi ketidaksantunan berbahasa Culpeper (1996) tidak sama seperti sarkasme dalam majas yang berupa penghinaan yang mengekspresikan rasa kesal dan marah dengan menggunakan kata-kata yang sangat kasar, melainkan menyerang muka target tidak secara terang-terangan dengan menggunakan kalimat yang lebih halus namun sebenarnya ditujukan untuk menghina lawan. Cirinya adalah ujaran yang tidak tulus, berpura-pura dan tampak santun di permukaan. Komentar tersebut berkonotasi negatif karena jika dikaitkan dengan konteks komentar dan alur komentar sebelumnya, terjadi perdebatan panas antara komentator dengan target, sehingga komentar "proud of you brother" berasal dari bahasa inggris yang artinya "bangga padamu saudara". Dalam konteks kalimatnya komentar tersebut merupakan bentuk sindiran untuk menghina target. Ujaran tersebut tidak tulus, berpura-pura dan hanya tampak santun di permukaan saja karena sebenarnya komentator tidak bangga kepada target, sebaliknya komentator menganggap target tidak realistis dan konsisten dengan apa yang dituliskannya terlihat dari komentar "santai itu ngatain orang bodoh, santai itu ngatain orang mabok agama trus bilangin orang harus waras dikit, emang saya gila apa mas? Itu yang dibilang santai".

e. Kombinasi Strategi Ketidaksantunan Sarkasme Dan Negatif

Kode data : 503/SS250/U2

2. thata_9013 Prestasi go internasional guys $;-\theta$ memalukan

Konteks komentar "Prestasi go internasional guys (-) memalukan" dituliskan oleh pemilik akun Instagram @thata_9013 untuk mengomentari postingan akun Instagram detikcom berupa video mengenai kasus Reynhard Sinaga, pria indonesia yang divonis penjara seumur hidup atas dakwaan memperkosa 48 pria yang diposting pada tanggal 7 Januari 2020. Target data komentar tersebut adalah Reynhard.

Sarkasme dalam strategi ketidaksantunan berbahasa Culpeper (1996) tidak sama seperti sarkasme dalam majas yang berupa penghinaan yang mengekspresikan rasa kesal dan marah dengan menggunakan kata-kata yang sangat kasar, melainkan menyerang muka target tidak secara terang-terangan dengan menggunakan kalimat yang lebih halus namun sebenarnya ditujukan untuk menghina lawan. Cirinya adalah ujaran yang tidak tulus, berpura-pura dan tampak santun di permukaan. Kata "prestasi" pada komentar "prestasi go internasional guys, memalukan" lazimnya disematkan pada tindakan-tindakan yang positif namun jika dikaitkan dengan konteks komentar tersebut komentator tidak benar-benar memuji Reynhard dengan mengatakan bahwa Reynhard membuat sebuah prestasi tetapi yang dimaksud adalah prestasi dalam hal keburukan karena tindak kriminal yang ia lakukan sehingga komentar tersebut mengandung ujaran yang tidak tulus dan berpura-pura. Komentar tersebut juga tampak santun di awal, namun niat target terlihat di akhir komentar dengan adanya pembubuhan kata "memalukan" yang ditujukan pada target.

Data tersebut juga termasuk strategi ketidaksantunan negatif karena mengandung ciri strategi ketidaksantunan negatif Culpeper 
(1996) yaitu unsur mencemooh, menghina dan meredahkan target. Komentator menyerang wajah negatif target dengan menyebutnya "memalukan" pada bagian akhir komentar tersebut.

\section{Kombinasi Tiga Strategi Ketidaksantunan} Berbahasa

a. Kombinasi Strategi Ketidaksantunan Langsung, Positif Dan Negatif Kode data : 337/SS196/U3

danangprymbd Malu2 in Tolol, Tembak Mati ajalah !!!

Konteks komentar "Malu2in Tolol, Tembak Mati ajalah!!!” dituliskan oleh pemilik akun Instagram @danangprymbd untuk mengomentari posting-an akun Instagram detikcom berupa video mengenai kasus Reynhard Sinaga, pria asal indonesia yang divonis penjara seumur hidup atas dakwaan memperkosa 48 pria yang diposting pada tanggal 7 Januari 2020. Target pada data komentar tersebut adalah Reynhard.

Termasuk dalam strategi ketidaksantunan secara langsung Culpeper (1996) karena pada data tersebut komentator menyerang target secara langsung tanpa penghalusan kalimat dengan komentar yang jelas, singkat dan tidak ambigu dengan menuliskan "malu2in tolol, tembak mati ajalah". Data tersebut memperlihatkan bahwa komentator memiliki niat yang jelas untuk melakukan ofensif maksimal terhadap target dengan meminta yang lain untuk menembak mati target. Komentator juga secara langsung menyerang wajah target dengan menyebutnya "tolol".

Komentar tersebut juga termasuk dalam strategi ketidaksantunan negatif karena mengandung ciri strategi ketidaksantunan negatif Culpeper (1996) yaitu mencemooh, menghina, dan merendahkan. Komentar "malu2in tolol" memperlihatkan bahwa komentator menyerang wajah negatif target dengan menyebut target tolol karena membuat malu.

Selain itu komentar tersebut juga termasuk dalam strategi ketidaksantunan berbahasa positif, karena menggunakan bahasa tabu dan mengandung unsur ketidaksimpatian yang merupakan salah satu ciri dari strategi ketidaksantunan positif Culpeper (1996). Bahasa tabu terlihat dari kata "tolol" yang digunakan komentator untuk menghina target, dan ketidaksimpatian terlihat dari komentator yang ingin target ditembak mati. Termasuk dalam kata tabu karena menyebut target yaitu Reynhard "tolol" merupakan kata makian. Kata makian dan tabu memiliki hubungan yang erat. Bahasa tabu adalah bahasa yang sifatnya tidak baik, sehingga seringkali dijadikan sarana melampiaskan emosi, oleh karena itu bahasa tabu sering dipakai sebagai makian. Penggunaan bahasa tabu merupakan salah satu ciri dari strategi ketidaksantunan berbahasa positif yang dikemukakan oleh Culpeper (1996).

b. Kombinasi Strategi Ketidaksantunan Positif, Negatif Dan Sarkasme

Kode data : 441/SS230/U5

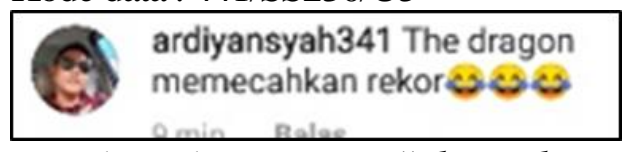

Konteks komentar "The dragon

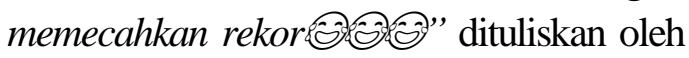
pemilik akun Instagram @ardiansyah341 untuk mengomentari posting-an akun Instagram detikcom berupa video mengenai kasus Reynhard Sinaga, pria indonesia yang divonis penjara seumur hidup atas dakwaan memperkosa 48 pria yang di-posting pada tanggal 7 Januari 2020. Target dalam data komentar tersebut adalah Reynhard.

Tergolong strategi ketidaksantunan berbahasa positif, karena penyematan "the dragon" untuk menyebut target dalam komentar tersebut merupakan sebuah penggunaan penanda identitas yang tidak tepat secara sengaja dan julukan menghina. "the dragon" merupakan bahasa inggris yang artinya "naga". Kata "naga" merupakan seekor hewan, sehingga tidak pantas disematkan untuk manusia. Penggunaan penanda identitas yang tidak tepat dan dan julukan yang menghina tersebut merupakan salah satu ciri dari 
strategi ketidaksantunan berbahasa positif yang dikemukakan oleh Culpeper (1996).

Selain itu komentar tersebut juga termasuk dalam strategi ketidaksantunan negatif karena mengandung ciri strategi ketidaksantunan negatif Culpeper (1996) yaitu unsur mengejek, menghina, dan merendahkan target. Komentator menyerang wajah negatif target dengan menyebut target "the dragon". Frasa "the dragon" berasal dari bahasa inggris yang artinya "naga" (hewan naga). Target yaitu Reynhard merupakan suku batak dengan marga Sinaga, jika kata tersebut dipenggal menjadi 2 bagian akan berbunyi "si naga". Kata "naga" dalam penggalan kalimat tersebut lah yang digunakan komentator untuk menghina tareget sehingga komentar tersebut mengandung unsur menghina, mengejek dan merendahkan target.

Komentar tersebut juga termasuk dalam strategi ketidaksantunan sarkasme atau kesantunan semu. Strategi ketidaksantunan berbahasa Culpeper (1996) tidak sama seperti sarkasme dalam majas yang berupa penghinaan yang mengekspresikan rasa kesal dan marah dengan menggunakan kata-kata yang sangat kasar, melainkan menyerang muka target tidak secara terang-terangan dengan menggunakan kalimat yang lebih halus namun sebenarnya ditujukan untuk menghina lawan. Ciri sarkasme atau kesantunan semu meliputi ujaran tidak tulus, berpura-pura dan tampak santun di permukaan. Frasa "memecahkan rekor" biasanya berkonotasi positif, namun pada komentar tersebut berkonotasi negatif karena rekor yang dipecahkan berupa kasus pemerkosaan terbesar sepanjang sejarah Inggris yang merupakan rekor dalam lingkup negatif sehingga komentar tersebut hanya tampak santun di permukaan dan mengandung unsur keberpura-puraan serta ketidaktulusan.

\section{KESIMPULAN}

Berdasarkan hasil penelitian strategi ketidaksantunan berbahasa yang dituturkan oleh masyarakat Indonesia pada kolom Instagram detikcom posting-an kasus
Reynhard Sinaga diperoleh bahwa strategistrategi tersebut tidak hanya digunakan secara tunggal, tetapi juga menunjukkan adanya penggunaan kombinasi antar strategi tersebut. Hal itu membuat penelitian ini berbeda dengan penelitian relevan lainnya yang hanya memaparkan penggunaan strategi ketidaksantunan berbahasa Culpeper (1996) secara tunggal.

Hasil penelitian menunjukkan penggunaan strategi ketidaksantunan berbahasa baik secara tunggal maupun kombinasi sebanyak 846 data, komentar dengan penggunaan strategi ketidaksantunan berbahasa secara tunggal sebanyak 300 data dan kombinasi strategi ketidaksantunan berbahasa sebanyak 546 data. Jika dirincikan dari data tersebut jumlah penggunaan strategi yang paling banyak ditemukan adalah strategi ketidaksantunan berbahasa negatif yaitu sebanyak 219 data. Strategi yang tidak ditemukan dalam penelitian ini adalah pemakaian strategi menahan kesantunan.

Peneliti berasumsi banyaknya komentar dengan bahasa yang tidak santun terjadi karena masyarakat merasa media sosial merupakan sarana ekspresi dan pelampiasan tanpa batas, terpicu pula oleh rasa tidak kenal, sehingga ada unsur pemahaman tak mengapa berkomentar tidak santun karena tak bertatapan muka dan bukan orang dekatnya, selain itu beberapa juga berlindung dengan akun palsu, yakni akun yang tak menggunakan identitas sebenarnya.

\section{DAFTAR PUSTAKA}

Achmad, D. P., Retnowaty, R., \& Musdolifah, A. (2020). STRATEGI KESANTUNAN BERBAHASA DALAM ACARA DEBAT CALON PRESIDEN DAN WAKIL PRESIDEN TAHUN 2019. Kompetensi, 13(2), 46-58.

Culpeper, J. (1996). Towards an anatomy of impoliteness. Journal of Pragmatics, 25(3),349-367. https://doi.org/10.1016/03782166(95)00014-3 
Damayanti, Rini S.Pd M.Hum, \& Indrayanti, T. S. P. M. P. (2015). Bahasa Indonesia Untuk Perguruan Tinggi. Victory Inti Cipta.

KBBI, 2016. Kamus Besar Bahasa Indonesia (KBBI) $V$. Tersedia online di https://kbbi.kemdikbud.go.id/

Mahsun. (2012). Metode Penelitian Bahasa. PT.Rajagrafindo Persada.

Moleong, P. D. L. M. . (2014). Metodologi Penelitian Kualitatif (edisi Revi). PT.Remaja Rosdakarya.

Retnowaty, R. (2015). Politeness Strategies Used by Colter Stevens as the Main Character in Source Code Movie. In UNNES International Conference on ELTLT (English Language Teaching, Literature, and Translation) (pp. 696-708).

Shinta, V. M., Hamzah, \& Wahyuni, D. (2018). Impoliteness Strategies Used By Supporters And Detractors Of Ahok In Their Online Comments By Gender. E-Journal of English Language \& Literature, 7(1), 1-12. www.google.com

Sugiyono, P. D. (2015). Metode Penelitian Pendidikan (pendekatan kuantitatif,kualitatif dan $R \& D)$. Alfabeta.

Suharsimi, A. (2010). Prosedur Penelitian: Suatu Pendekatan Praktik. Rineka Cipta. 